\title{
ANALYSIS OF STUDENT ERRORS IN COMPLETING PISA CONTENT SPACE AND SHAPE PROBLEMS VIEWED FROM VAK LEARNING STYLE
}

\author{
Hanifah Kirania Ulfah \\ Mathematics Education, Faculty of Mathematics and Natural Sciences, Universitas Negeri Surabaya \\ e-mail: hanifahulfah@mhs.unesa.ac.id \\ Yusuf Fuad \\ Mathematics Education, Faculty of Mathematics and Natural Sciences, Universitas Negeri Surabaya \\ e-mail: yusuffuad@unesa.ac.id
}

\begin{abstract}
Trends in International Mathematics and Science Study (TIMSS) study and the Program for International Student Assessment (PISA) is one of the principles in curriculum development in Indonesia. Judging from the results of the PISA study, the achievements obtained by Indonesian children especially in the aspects of mathematical literacy have not been satisfactory. The low achievement is inseparable from the learning process in schools, one of which students are not accustomed to solving questions with characteristics such as the PISA context. In addition, the way students absorb information also determines how learning achievements will be obtained by students. The way students learn is often referred to as a learning style. This indicates that the mathematics literacy of junior high school students in Indonesia is so weak that they still have difficulty in solving PISA questions. As a result, many mistakes were made by junior high school students when faced with PISA questions. The purpose of this study was to describe the errors of students with visual, auditory, and kinesthetic learning styles in solving space and shape content PISA questions. Students' errors were analyzed from the adaptation of Newman's error analysis model namely comprehension, transformation, proccess skills, and encoding. This type of research is qualitative descriptive. Data collection techniques that be used are tests and interviews. The results showed that students with visual learning styles tend to make mistakes in the transformation step. Whereas students with auditory learning styles tend to make mistakes in understanding and transformation steps, and students with kinesthetic learning styles make mistakes in the steps of understanding, transformation, and process skills. This shows that students who have kinesthetic learning styles do not have a tendency in one type of error.

Keywords: Error analysis, PISA, VAK Learning Style
\end{abstract}

\section{INTRODUCTION}

Learning in the $21^{\text {st }}$ century has a principle that must be student-centered, collaborative, contextual, and integrated with the community. The role of the teacher in implementing learning is very important in realizing the future of the nation's children who can compete in the era of globalization. Active and student-centered learning according to EIC in 2004 will provide opportunities for students to develop their perceptual framework, develop effective learning, use different learning approaches for each student according to their learning style so as to develop their creativity.

Students who are able to think high or often called the Higher Order Thinking Skill (HOTS) will be able to compete in the global world. Research conducted by Ramirez and Ganaden (2008) shows that creative activities can improve abilities (Handayani \& Priatmoko, 2013).
PISA is one of the foundations in curriculum development in Indonesia (Kemendikbud, 2013). Various types of tests held internationally can be used as a benchmark to determine the extent to which Indonesian students are able to compete in the current era of globalization, including PISA tests. PISA aims to evaluate education systems throughout the world by testing the skills and knowledge of 15 -year-old students. Judging from the results of the PISA study, the achievements obtained by Indonesian children especially in the aspects of mathematical literacy have not been satisfactory.

It can be seen from the PISA results of students' mathematical literacy as of 2000 placing Indonesia at position 39 of 41 countries with a value of 367, in 2003 in the position of 38 out of 40 countries with a value of 360 , in position 50 in 57 countries with a value of 391, 2009 at 61 st position from 65 countries with a value of 371, in 2012 at 64 th position from 65 countries with a value of 375 . In 
2015 it was in position 63 of 70 countries with a value of 386 (OECD, 2016).

Some studies suggest that students' ability to solve PISA problems in space and shape content is still low. Johar and Zainabar's research (2014) showed that only 15\% of students managed to solve PISA problems (score 4), 5\% of students who solved with a score of $3.20 \%$ students only wrote known data and things asked (score 1), and most students as much as $60 \%$ did not write anything in the answer (score 0).

To ensure mistake made by students, analysis is needed to determine the mistake made by students. According to Wijaya in 2014 to analyze errors in solving real problems such as PISA, Newman developed a model commonly referred to as Newman Error Analysis (NEA) consisting of 5 categories of errors, namely reading (reading), comprehension, transformation (transformation), process skills (process skill), and encoding.

According to Subanji in 2015 students' mathematical errors need to get attention because if they are not addressed immediately, these errors will have an impact on the next mathematical problem. The fewer mistakes made by students, the higher the student learning outcomes, and vice versa the more mistakes students make, the lower the student learning outcomes (Sofianingsih \& Kusmanto, 2017). This can affect student achievement. Learning achievement is the result achieved from the results of training, experiences supported by consciousness (Suryabrata, 2002: 23)

Some factors that can influence student achievement are both internal factors and external factors. The way students absorb information may determines how learning achievements will be obtained by students (Damayanti, 2016). Each student has different ways of absorbing / receiving information that is conveyed by the teacher. This causes the learning outcomes and achievements of each student to be different. The way students learn is often referred to as a learning style.

\section{METHOD}

This research was qualitative descriptive. To get the data that was needed in this study researchers used qualitative data. Supporting instruments that were used in this study include: Questionnaire of Multiple Intelligence (AKM), Question of Mathematics Ability Test (TKM), Question of PISA Content Space and Shape (TSP). The research was taken in $8^{\text {th }}$ grade of SMP Labscool UNESA Surabaya, in the even semester of $2018 / 2019$.

\section{RESULT AND DISCUSSION}

The selection of research subjects begins with class assignments. There are 2 classes in the UNESA Surabaya Labschool Middle School, namely classes $8^{\text {th }} \mathrm{A}$ and $8^{\text {th }} \mathrm{B}$.
Based on the results of observations and suggestions from mathematics teachers at the school, researchers purposively chose class $8^{\text {th }} \mathrm{B}$ consisting of 30 students. The purposive selection that is meant is that the researcher determines specific characteristics which are in accordance with the research objectives. Specific features in question are students who have obtained material in the field of geometry in class $8^{\text {th }} \mathrm{B}$. Next, the researcher gave a learning style test (TVAK). Each type of student learning style was obtained with the details of 6 students included in the visual learning style group, 6 students included in the auditory learning style group, and 5 students included in the kinesthetic learning style group.

After giving TVAK, the researcher then gave a Mathematics Ability Test (TKM) to all $8^{\text {th }} \mathrm{B}$ grade students. Based on the results of the TKM given, there were high, medium, and low category values according to each group of learning styles. The following are presented in the TKM values for each group of learning styles.

Table 1 TKM Score in Visual Students

\begin{tabular}{|c|c|}
\hline Name of Students & TKM Score \\
\hline ANZK & 55 \\
\hline AMM & - \\
\hline AA & 0 \\
\hline FSS & 0 \\
\hline RRJNKH & - \\
\hline RGZ & 55 \\
\hline
\end{tabular}

Table 2 TKM Score in Auditory Students

\begin{tabular}{|c|c|}
\hline Name of Students & TKM Score \\
\hline APA & 18 \\
\hline ESOH & 10 \\
\hline IGKDP & 40 \\
\hline IKAN & 0 \\
\hline MAH & 30 \\
\hline OWG & 10 \\
\hline
\end{tabular}

Table 3 TKM Score in Kinesthetic Students

\begin{tabular}{|c|c|}
\hline Name of Students & TKM Score \\
\hline CTA & 0 \\
\hline FNMC & - \\
\hline MHHR & 0 \\
\hline RSPS & 60 \\
\hline VSP & 28 \\
\hline
\end{tabular}

After giving TKM, the researcher gave TSP to all $8^{\text {th }} \mathrm{B}$ grade students. Based on the results of TSP, the types of student errors were obtained in each learning style group.

In choosing the subject of the research, the researcher looks at the value of the TKM and the variation in the types of TSP errors that have been given to students according to the indicators set out in the Table 4.

\section{Table 4 Indicators Error Analysis}




\begin{tabular}{|c|c|c|}
\hline Code & Types of Error & Indicators \\
\hline \multirow[t]{3}{*}{$\mathrm{C}$} & \multirow[t]{3}{*}{ Comprehension } & $\begin{array}{l}\text { Students cannot mention } \\
\text { what is known in full. }\end{array}$ \\
\hline & & $\begin{array}{l}\text { Students do not identify } \\
\text { what is known precisely so } \\
\text { that it causes } \\
\text { misinterpretation. }\end{array}$ \\
\hline & & $\begin{array}{l}\text { Students do not read } \\
\text { questions carefully so that } \\
\text { there is information } \\
\text { missing. }\end{array}$ \\
\hline \multirow[t]{2}{*}{$\mathrm{T}$} & \multirow[t]{2}{*}{ Transformation } & 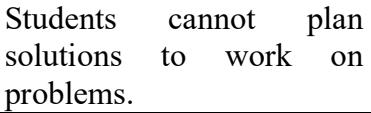 \\
\hline & & $\begin{array}{l}\text { Students are wrong in } \\
\text { determining the formula. }\end{array}$ \\
\hline $\mathrm{P}$ & Process Skill & $\begin{array}{l}\text { Students are not careful in } \\
\text { doing calculations or } \\
\text { computing. }\end{array}$ \\
\hline$E$ & Encoding & $\begin{array}{l}\text { Students cannot provide } \\
\text { conclusions about the right } \\
\text { answer. }\end{array}$ \\
\hline
\end{tabular}

There are 3 students, 1 visual student, 1 auditory student, and 1 kinesthetic student. Subject that was got as the following:

Table 5 The Subject of Research

\begin{tabular}{|c|c|c|}
\hline No & Name & Code \\
\hline 1 & RGZ & SP1 \\
\hline 2 & IGKDP & SP2 \\
\hline 3 & RSPS & SP3 \\
\hline
\end{tabular}

Analysis of Student Errors in Working on PISA Questions Space and Shape Content Viewed from Learning Styles

The type of errors data from TSP can be showed in Table 6.

Table 6 Data Of Type of Errors of Student

\begin{tabular}{|l|l|c|c|c|}
\hline Types Of Error & \multicolumn{1}{|c|}{ Indicator } & \multicolumn{3}{|c|}{ Number Of Question } \\
\cline { 2 - 5 } & & $\mathbf{V}$ & $\mathbf{A}$ & $\mathbf{K}$ \\
\hline Comprehension & $\begin{array}{l}\text { Mention what is } \\
\text { known }\end{array}$ & - & - & - \\
\cline { 2 - 5 } & $\begin{array}{l}\text { Identify what is } \\
\text { known in the } \\
\text { problem }\end{array}$ & 1 & 1, & - \\
\cline { 2 - 5 } & $\begin{array}{l}\text { Read the } \\
\text { question }\end{array}$ & 3 & - & 3 \\
\hline Transformation & $\begin{array}{l}\text { Plan a solution } \\
\text { to solve the } \\
\text { problem }\end{array}$ & $2 . \mathrm{b}$ & $2 . \mathrm{a}$, & 1 \\
\cline { 2 - 5 } & $\begin{array}{l}\text { Determine the } \\
\text { formula }\end{array}$ & $4 . \mathrm{b}$ & 3 & - \\
\hline Process Skill & $\begin{array}{l}\text { Do calculating or } \\
\text { computing }\end{array}$ & - & - & $4 . \mathrm{b}$ \\
\hline
\end{tabular}

\begin{tabular}{|l|ll|l|l|l|}
\hline Encoding & $\begin{array}{l}\text { Give } \\
\text { conclusion }\end{array}$ & a & - & - & - \\
\hline
\end{tabular}

Analysis of Student Errors in Working on PISA Questions Space and Shape Content Viewed from Visual Learning Styles

The results of the analysis show that there are 6 students of the type of visual learning style. Students who are of the type of visual learning style are happy with skills. In addition, students with a visual learning style are also not easily disturbed when working on a problem when there is a commotion so they can still read in noisy conditions. Students who are of the type of visual learning style do not like to talk while working on something. This situation is in accordance with the characteristics of students who have the type of visual learning style according to DePorter \& Hernacki (2012) which is not disturbed by noise.

Students with visual learning styles when working on PISA problems in space and shape content tend to make mistakes in problem transformation errors. But students also make mistakes in understanding the questions and process skills.

Students with comprehension errors are found in questions number 1 and 3 . This is indicated by subjects who cannot read the questions carefully so that there is information missing. So as to make the student answer the question incorrectly and not in accordance with the question in question. The situation is in accordance with students of the type of visual learning style, according to DePorter \& Hernacki (2012) characteristics of students who have a visual learning style, one of which is a fast and diligent reader. However, students of the learning style type write written sentences known and asked in detail and detail. This is because according to DePorter \& Hernacki (2012) students of the type of visual learning style have meticulous nature of detail and are neat and orderly.

Students with transformation errors are found in questions number $2 . \mathrm{b}$ and number $4 . \mathrm{b}$. Students are not able to use the right strategy or way to solve the problem. This error includes students unable to determine the solution, method or formula to solve the problem. This is in accordance with the statement of Opticia (2016) that students of the type of visual 
learning style do not like to memorize so that students do not know what formulas or ways to use.

Students with process skills errors are found in questions number 1. Error in process skills is indicated by subjects who are not careful in doing calculations or computation so students cannot find the right answers. This is in accordance with the statement of Opticia (2016) that students of the type of visual learning style are weak in calculating.

Meanwhile there was no error in the writing of the final answer (encoding). This is also caused because according to DePorter \& Hernacki (2012) the nature of students has a neat and systematic visual learning style so that even if the work is wrong, the writing of the answer is finally complete.

Analysis of Student Errors in Working on PISA Questions Space and Shape Content Viewed from Auditory Learning Styles

There were 6 students with auditory learning styles. Students with auditory learning styles like to talk and discuss with their friends at length. In addition, students with auditory learning styles are also easily disturbed when working on questions when there is a commotion. Students with auditory learning styles like to talk to themselves when doing something. This situation is in accordance with the characteristics of students with auditory learning styles according to DePorter \& Hernacki (2012). Based on the research subject for students with auditory learning styles, namely when working on PISA space and shape content, students tend to make mistakes in the transformation indicator. But students also make mistakes in the indicator of understanding.

The comprehension errors made by students are found in questions number 1 and 4.b. This is indicated by students who are unable to explain the information contained in the question correctly so that students are unable to identify what is known and what is asked in the question correctly. In question number 1 , students do not understand the meaning of the whole question so that they are not consistent in identifying known questions. So that students cannot solve the questions correctly because they misunderstand the meaning of the question. In question number $4 . b$, students are not able to explain the information contained in the question correctly so that the information obtained is wrong and affects the end result and does not get the results correctly. This situation is in accordance with students of the type of auditory learning style, according to DePorter \& Hernacki (2012) characteristics of students who have auditory learning styles, one of which is easily disturbed by noise so that class conditions and conditions will affect them when understanding the information they are capturing .

Mistakes of transformation made by students are found in questions number 2.a, number 3, and number 4.a. Basically, transformation errors are indicated by subjects who are unable to use the right strategy or way to solve the problem. This error includes students unable to determine the solution, method or formula to solve the problem.In question number 2.a, students cannot plan solutions to work on the problem so that the results obtained are incorrect. In question number 3 students cannot determine what formula is used to solve the problem. This situation is in accordance with students with auditory learning style, according to Opticia (2016), namely the characteristics of students who have auditory learning styles, one of which is not like memorizing.

Meanwhile there was no mistake in the process skill process. Judging from the results of his work, students in auditory learning styles often write briefly, but when confirmed in interviews, they can be explained correctly. This is also due to according to DePorter \& Hernacki (2012) the nature of auditory learning style students who say students in auditory learning style have problems related to visual things such as writing but great in speaking

There is no error in the writing of the final answer (encoding). This is because students make mistakes before encoding which means students do not make encoding errors.

Analysis of Student Errors in Working on PISA Questions Space and Shape Content Viewed from Auditory Learning Styles

There were 5 students of the type of kinesthetic learning style. Based on the research subject for students with kinesthetic learning styles, when working on PISA space and shape content, students tend to make the main mistakes in all types of errors except for the writing of the final answer (encoding). varied. 
Based on the data analysis that has been done, comprehension made by students is found in number 3. Students do not read the questions carefully so that there is information missing. So that students cannot answer questions correctly.

Based on the data analysis that has been done, the error of transformation carried out by students is found in question number 1. Basically the transformation error is indicated by the subject who is not able to use the right strategy or way to solve the problem. This error includes students unable to determine the solution, method or formula to solve the problem. in number 1 , students cannot determine what formula is used to solve the problem correctly. Judging from the results of work, students in kinesthetic learning styles often try to solve problems by using their own strategies. Although their "trial and error" strategies are often wrong concepts but this is consistent with the opinion of De Porter \& Hernacky (2008) which states that students with kinesthetic learning have the character of wanting to do everything (trying new things) and learning through manipulation and practice. The cause of this error is the lack of understanding of the wide-ranging material so that after understanding what is meant by the problem, students do not know how to solve it.

Based on the data analysis that has been done, errors in process skills performed by students are found in number $4 \mathrm{~b}$. Process skill errors are indicated from subjects who are not careful in performing calculations or computation.

Meanwhile there was no error in the writing of the final answer (encoding). This is because students make mistakes before encoding which means students do not make encoding errors.

\section{The Difference in Student Errors Working on PISA Questions in Space and Shape Content Based on VAK Learning Styles}

The following is the difference in student errors working on pisa questions in space and shape content based on vak learning styles from the four aspects of types of error, comprehension, transformation, process skill, and encoding.. There are seven indicators. Table 6 shows the total differences in each types of error of the indicators given.

Based on the table above, it could be seen that linguistic students have good mathematical communication skills on aspects of fluency. While logical-mathematical student have mathematical communication skills that are good on aspects of complexity and fluency.

\section{CLOSURE}

\section{Conclusion}

Students with visual learning styles tend to make mistakes in the transformation step.

Students with auditory learning styles tend to make mistakes in the steps of understanding and transformation.

Students with kinesthetic learning styles make mistakes in the steps of understanding, transformation, and process skills. This shows that students who have kinesthetic learning styles do not have a tendency in one type of error.

\section{Suggestions}

Based on the results of the research that has been obtained, the following researchers provide suggestions for further research.

\section{REFERENCES}

Ahmadi , A., \& Supriyono, W. (2008). Psikologi Belajar. Jakarta: Rineka Cipta.

Bire, A. L., Geradus, U., \& Bire, J. (2014). Pengaruh gaya Belajar Visual, Auditori dan Kinestetik Terhadap Prestasi Belajar Siswa. Jurnal Kependidikan, Vol.44, No.2.

Damayanti, L. (2016). Hubungan Gaya Belajar Siswa Dengan Hasil Belajar IPS Pada Siswa Kelas V SDN Di Gugus Wibisono Kecamatan Jati Kabupaten Kudus.

Deporter, B., \& Hernacki, M. (2002). Quantum Learning Membiasakan Belajar Nyaman dan Menyenangkan Buku Pengembangan Diri. Mizan Publishing.

Dinni, H. N. (2018). HOTS (High Order Thinking Skills) dan Kaitannya dengan Kemampuan Literasi Matematika. PRISMA, Vol 1, hlm. 170.

Ghufron, Nur, M., \& Risnawita, R. (2014). Gaya Belajar Kajian Teoritik.

Gilakjani, A. P. (2012). Visual, auditory, kinaesthetic learning styles and their impacts on engliah language teaching. Macrothink Institute. 
Handayani, R., \& Priatmoko, S. (2013). Pengaruh Pembelajaran Problem Solving Berorientasi HOTS (Higher Order Thinking Skills) Terhadap Hasil Belajar Kimia Siswa Kelas X. Inovasi Pendidikan Kimia, Vol 7, 1051-1062.

Harahap, Sofyan Syarif. 2004. Analisis Kritis Atas Laporan Keuangan. Jakarta. PT Raja Grafindo Persada

Johar, R., \& Zainabar. (2014). Students`Performance on Shape and Space Task of PISA Question. International Conference on Special Education 2013, 449-454.

Julianingsih, S. (2017). Pengembangan Instrumen Asesmen Higher Order Thinking Skill (HOTS) Untuk Mengukur Dimensi Pengetahuan IPA Siswa Di SMP.

Ketterline-Geller,L.R \& Yovanoff,P.(2009). Diagnostic assessments mathematicstop support instructional decisionmaking. Practical Assessement,Research \& Evaluation, 14(16), hlm.2-11.

Kemendikbud. (2016, Desember 06). Peringkat dan Capaian PISA Indonesia Mengalami Peningkatan. Retrieved from Kementerian Pendidikan dan Kebudayaan : www.kemendikbud.go.id

Mahdiansyah dan Rahmawati. 2014. Literasi Matematika Siswa Pendidikan Menengah: Analisis menggunakan Desain Tes Internasional dengan Konteks Indonesia.Jurnal Pendidikan dan Kebudayaan, 20(4), 452-569.

Nasution, S. (2010). Berbagai Pendekatan dalam Proses Belajar dan Mengajar. Jakarta: Bumi Aksara.

Newman, M. (1977). An Analysis of Sixth-grade Pupils' Error on Written Mathematical Task. Victorian Institute for Educational Research Bulletin, 39, 31-43.

Novita, R., Zulkardi, \& Hartono, Y. (2012). Exploring Primary Student's Problem

Solving Ability by Doing Tasks Like PISA's Question . IndoMS. J.M.E , 133-150.

OECD. (2013). PISA 2012 Assessment and Analytical Framework. OECD Publishing.

OECD. (2015). PISA 2015 Draft Mathematics Framework. New York: Columbia UniversityPISA 2015 Draft Mathematics Framework. (2013).

Ramadani, R., Mustamin, H., \& Idris, R. (2017). Hubungan Antara Kreativitas Guru Dan
Gaya Belajar Siswa Dengan Hasil Belajar Matematika Siswa Kelas X SMA Negeri 1 Bontomarannu Kabupaten Gowa. Jurnal Matematika dan Pembelajaran, Volume 5 No 1, 84.

Ramirez, \& Ganaden. (2008). Creative Activities and Students' Higher Order Thinking Skills. Education Quarterly, Vol.66, no.1, 22-23.

Rokhimah, S., Suyitno, A., Sukestiyarno Y.L.(2015). Students Error Analysis in Solving Math Word Problems of Social Arithmetic Material for 7th Grade Based on Newman Procedure. Proceeding Unnes

Saifulloh, M., Muhibbin, Z., \& Hermanto. (2012). Strategi Peningkatan Mutu Di Sekolah. Jurnal Sosial Humaniora, Vol 5 No.2, November 2012, Vol 5 No.2.

Saleh, K., Yuwono, I., As'ari, A. R., \& Sa'dijah, C. (2016). Errors Analysis Solving Problems Analogies by Newman Procedure Using Analogical Reasoning. International Journal of Humanities and Social Sciences, Vol. 9 No.1, pp. 17-26.

Stacey, K. \& Turner, R (2015). PISA's Influence on Thought and Action in MathematicsEducation.Switzerland: Springer Netherlands, 277-306.

Subini, N. (2012). Mengatasi Kesulitan Belajar pada Anak. Jogjakarta: Javalitera.

Sukadi. (2008). Progressive Learning. Bandung: Niaga Qolbum Salim.

Sukardi, D. K. (2000). Pengantar Pelaksanaan Program Bimbingan dan Konseling di Sekolah. Jakarta: PT Rineka Cipta.

Sumule, U. (2017). Analisis Kesalahan Siswa Kelas VII Dalam Menyelesaikan Soal PISA Konten Space and Shape Dengan Menggunakan Prosedur Newman. Tesis.

Tarigan, Henry Guntur. (2011). Pengajaran Analisis Kesalahan Berbahasa. Bandung: Angkasa

Trisdiono, H. (2015). Pembelajaran Aktif dan Berpusat pada Siswa sebagai Jawaban Atas. Widyaiswara LPMP D.I. Yogyakarta.

V Chislett MSc \& A Chapman. 2005. VAK Learning Styles Self-Assessment Questionnaire. http:/ / www.businessballs.com/vaklearnin gstylestest.htm Diambil 20 November 2018. 
Wardhani, S., \& Rumiati. (2011). Instrumen penilaian hasil belajar matematikaSMP: Belajar dari PISA dan TIMSS. Yogyakarta.

Wijaya, A. (2012). Pendidikan Matematika Realistik: Suatu Alternatif Pendekatan Pembelajaran Matematika.

Wijaya, A., Heuvel-Panhuzen, M. V., Doorman, M., \& Robitzsch, A. (2014). Difficulties in solving context-based PISA mathematics tasks: An analysis of students' errors. The Mathematics Entusiast, Vol. 11, 561.
Winkel, W. (2007). Psikologi Pengajaran. Jakarta: PT. Grasindo Persada.

Wiradi. 2006. Analisis Sosial. Bandung: Yayasan AKATIGA

Zubaidah, S. (2016). Keterampilan Abad Ke-21 : Keterampilan Yang Diajarkan Melalui Pembelajaran.Seminar Nasional Pendidikan dengan Tema "Isu-isu Strategis Pembelajaran MIPA Abad 21. Sintang - Kalimantan Barat 